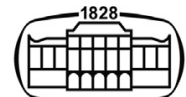

AKADÉMIAI KIADÓ

\section{Acta Veterinaria}

Hungarica

$68(2020) 3,242-250$

DOl:

$10.1556 / 004.2020 .00050$

(c) 2020 The Author(s)

\section{RESEARCH ARTICLE}

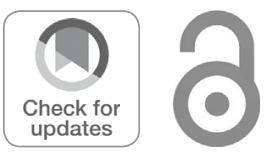

\title{
Evaluation of the performance of a human D-dimer test in dogs with neoplasia
}

\section{BEÁTA TÖRÖK-NAGY ${ }^{1}$, PÉTER VAJDOVICH ${ }^{2}$, LAJOS BALOGH ${ }^{3}$, JULIANNA THURÓCZY ${ }^{4}$ and BÉLA DÉNES ${ }^{5 *}$}

\author{
${ }^{1}$ Doctoral School of Veterinary Science, University of Veterinary Medicine, Budapest, Hungary \\ ${ }^{2}$ Department of Clinical Pathology and Oncology, University of Veterinary Medicine, Budapest, \\ Hungary \\ ${ }^{3}$ National Research Institute for Radiobiology and Radiohygiene, Budapest, Hungary \\ ${ }^{4}$ Gamma-VET Ltd., Budapest, Hungary \\ ${ }^{5}$ Veterinary Diagnostic Directorate, National Food Chain Safety Office, Tábornok u. 2, H-1143 \\ Budapest, Hungary
}

Received: April 15, 2020 • Accepted: May 19, 2020

Published online: November 3, 2020

\begin{abstract}
The goal of this study was to evaluate the suitability of a commercially available D-dimer assay as a diagnostic tool for testing dogs. This assay is an immunoturbidimetric diagnostic test, capable of determining the $\mathrm{D}$-dimer levels in human plasma by using 2B9 monoclonal antibody. Plasma samples of clinically healthy $(n=20)$ and tumour-bearing $(n=50)$ dogs were measured. The tumours were grouped on the basis of histological type and aggressiveness, and then the measured D-dimer concentrations of these groups were compared to those of the control group. The differences were analysed statistically. For benign tumours, we did not find alterations in the D-dimer levels. However, in the case of malignant tumours (lymphoma, sarcoma, and carcinoma) and in the presence of metastases, significantly elevated D-dimer levels were measured. The assay proved to be suitable for measuring the D-dimer levels in plasma samples of dogs. The calculated reference range for dogs was confirmed to be between 0.06 and $0.69 \mu \mathrm{g} / \mathrm{mL}$ fibrinogen equivalent unit.
\end{abstract}

\section{KEYWORDS}

D-dimer, diagnostic test, dogs, neoplasia, tumour

\section{INTRODUCTION}

D-dimer is a cross-linked fibrin degradation product, the level of which increases in the blood during secondary fibrinolysis. In human medicine, deep vein thrombosis and pulmonary embolism are usually excluded by the determination of D-dimer concentration and a negative test result referring to a strictly determined cut-off level (Olson et al., 2011). The increase in D-dimer levels is not a disease-specific condition and may result from multiple causes. Therefore, it is not possible to set up a precise diagnosis based exclusively on the increase of D-dimer levels.

A connection between malignancy and thrombosis has been observed, as thromboembolism is present in almost half of cancer patients (Falanga and Rickles, 1999). Tumour cells can cause thrombosis by activating the blood clotting cascade or inhibiting the anticoagulant properties of vascular endothelial cells, monocytes, macrophages and platelets.

Based on human clinical studies, Nagy et al. (2012) reported a correlation between tumour aggressiveness and increased levels of D-dimer and suggested its potential use as a prognostic marker. Different tumour types have been examined and a correlation was found between elevated D-dimer levels in patients diagnosed with lung (Gabazza et al., 1993; Altiay et al., 2007), breast (Blackwell et al., 2000; Dirix et al., 2002; Khan et al., 2007),
Tel.: +36306913500

E-mail: denesb@nebih.gov.hu 
musculoskeletal (Morii et al., 2008), prostate (Adamson et al., 1993; Nakashima et al., 1995; Khoury et al., 2010), cervical (Gadducci et al., 1993) and colon (Kilic et al., 2008) cancers. However, articles investigating D-dimer levels of dogs with cancer are sporadic in the veterinary literature (Andreasen et al., 2012; de la Fuente et al., 2014; Font et al., 2015; Kang et al., 2016).

Based on the limited research data, we assumed that increased D-dimer levels would occur in dogs with malignant tumours. In order to test this hypothesis, we collected plasma samples from both tumour-bearing and clinically healthy dogs and analysed them with a human D-dimer test. Another purpose of this work was to evaluate the suitability of this assay as a diagnostic tool for malignant tumours on canine plasma samples.

The significance of $\mathrm{D}$-dimer level determination in dogs is primarily in the diagnosis of pulmonary embolism and disseminated intravascular coagulation (DIC), but its levels may also be elevated in other diseases like thromboembolic diseases, bleeding, kidney, heart and liver failure, postoperative conditions and different types of cancers (Stokol, 2003; Giannoulopoulos et al., 2017). Nelson and Andreasen (2003) examined healthy dogs and dogs with pulmonary embolism. They found D-dimer concentrations under 250 $\mathrm{ng} / \mathrm{mL}$, corresponding to $0.5 \mu \mathrm{g} / \mathrm{mL}$ fibrinogen equivalent unit (FEU) in the control group, but concentrations were $2,000 \mathrm{ng} / \mathrm{mL}(4 \mu \mathrm{g} / \mathrm{mL} \mathrm{FEU})$ for the dogs with pulmonary embolism. Tick et al. (2008) came to the conclusion that high D-dimer values have a significant correlation with pulmonary embolism. Examining the diagnostic significance of D-dimer concentration in dogs with pulmonary embolism Epstein et al. (2013) reported that the application of a 250 $\mathrm{ng} / \mathrm{mL}(0.5 \mu \mathrm{g} / \mathrm{mL}$ FEU $)$ cut-off value made it possible to exclude pulmonary embolism with confidence.

Another thromboembolic disease affecting dogs is DIC, a severe thromboembolic and haemorrhagic disorder, always in the setting of some other disease, such as neoplasia, infection, pancreatitis, myocardial infarction, or immunemediated haemolytic anaemia (IMHA) (Stokol et al., 2000). The diagnosis of DIC is not straightforward, and a definitive diagnosis can only be set up based on the results of several clinical examinations and laboratory tests (Giannoulopoulos et al., 2017). Stokol et al. (2000) examined 20 dogs suffering from DIC and 30 healthy dogs, and measured D-dimer levels by latex agglutination and immunoturbidimetric tests. They found that the average value for $\mathrm{D}$-dimer concentration was higher in dogs with DIC than in healthy dogs. Several additional studies provide information on D-dimer concentration in dogs suffering from DIC. Caldin et al. (2000), Griffin et al. (2003) and Machida et al. (2010) found that D-dimer was useful as a diagnostic marker of DIC.

Based on data available in the veterinary literature, in most cases the $\mathrm{D}$-dimer values were measured with assays intended for the measurement of human plasma samples utilising anti-human D-dimer monoclonal antibodies (Griffin et al., 2003; Stokol, 2003; Nelson, 2005; Machida et al., 2010). According to the principles of the measurement, there are immunoturbidimetry tests, such as Tina- quant $^{\circledR}$ D-dimer (Boehringer Mannheim) (Caldin et al., 2000; Stokol et al., 2000), latex agglutination tests, like Accuclot $^{\mathrm{TM}}$ D-dimer (Sigma Chemical Co, St Louis, MO) (Stokol et al., 2000; Nelson et al., 2009), and the NycoCard ${ }^{\circledR}$ point-of-care test based on an immunometric flow-through principle (Axis-Sheild PoC AS ${ }^{\mathrm{TM}}$ ) (Dewhurst et al., 2008).

Such tests were validated for use in the canine species (Giannoulopoulos et al., 2017), by applying a cut-off value adjusted for dogs. Griffin et al. (2003) examined dogs using a qualitative rapid immunochromatography diagnostic assay especially designed for use in the determination of $\mathrm{D}$-dimer levels in canines; however, this test is no longer available commercially (Giannoulopoulos et al., 2017). To the best of our knowledge, no commercially available $\mathrm{D}$-dimer diagnostic test specified for the analysis of canine plasma samples exists.

As mentioned above, the objective of the current work was twofold: (1) to evaluate the suitability of a commercially available human $\mathrm{D}$-dimer test for $\mathrm{D}$-dimer concentration measurement in dog plasma, and (2) to determine D-dimer concentration in plasma samples of dogs living with cancer and to assess the correlation between the presence of the tumour, the tumour type based on histology, tumour aggressiveness and D-dimer levels.

\section{MATERIALS AND METHODS}

\section{Collection and handling of samples}

We collected 70 plasma samples from dogs with the aid of the Veterinary Haematology and Oncology Centre and the Animal Health Centre of Budafok (Budapest, Hungary). The blood samples were placed in VACUETTE ${ }^{\circledR}$ (Greiner AG, Kremsmünster, Austria) phlebotomy tubes containing sodium citrate buffer, then the plasma was retrieved by centrifugation $(2,000 \times g, 10 \mathrm{~min})$.

\section{Study population}

The mean age of the dogs was 8 years and 2 months (1.5-14 years). The sex distribution was 52\% males and $48 \%$ females. The examined animals represented 22 dog breeds, and 20 dogs were of mixed breed. Fifty samples were collected from dogs diagnosed with different types of tumours. The abovedescribed population had the following classification based on the histological tumour types: mast cell tumour $(n=6)$, lymphoma $(n=5)$, sarcoma $(n=10)$, carcinoma $(n=17)$, insulinoma $(n=3)$, lipoma $(n=3)$, adenoma $(n=3)$, and other tumour types $(n=3)$, where tumours could not be classified into any of the previous groups.

The population of the tumour-bearing dogs is presented in Table A1. The control group consisted of 20 dogs judged to be clinically healthy. They were regularly vaccinated, treated with antiparasitic medicines and checked by a veterinarian. Animals that had no apparent illness or abnormalities detectable on cursory examinations were considered clinically healthy (Weiser and Allison, 2012).

All dogs underwent a clinical examination for complete systemic evaluation, health or diagnosis of tumour types, 
and classification of body condition. Tumour diagnosis was made with the help of surgical interventions aimed at incisional or excisional biopsy and histopathological (immunohistopathological) examinations. Preoperative clinical evaluation included peripheral blood sampling for complete blood count, routine serum biochemical analyses for ionogram, total protein, albumin, liver function and kidney function. All dogs were clinically tested for vascular or bleeding disorders by platelet indices, buccal mucosal bleeding time tests and clinical diagnostic imaging techniques. Thoracic radiological (laterolateral right, laterolateral left and ventral-dorsal), and abdominal ultrasound examinations were performed to assess the presence of metastases. In some cases, computed tomography and magnetic resonance imaging examinations were also performed. Clinical stage classification was performed on the basis of tumour size $(\mathrm{T})$, involvement of regional lymph nodes $(\mathrm{N})$, and presence or absence of distant metastases $(\mathrm{M})$, based on the TNM system (Owen, 1980). The macroscopic evaluation of regional lymph nodes was performed by palpation. If even a slight enlargement was observed, neoplastic involvement was confirmed by histopathological examination of excised lymph nodes.

\section{Quantitative determination of D-dimer level}

The canine plasma samples were tested by the Dia-D-Dimer immunoturbidimetric diagnostic assay (Diagon Ltd., Budapest, Hungary) that has been developed recently, based on a newly identified D-dimer specific monoclonal antibody 2B9 (Török-Nagy et al., 2019a). The test was validated for the analysis of human plasma samples by comparison to commercially available tests (Török-Nagy et al., 2019b). Ddimer concentrations were determined by turbidity measurements, performed on a Coag XL coagulometer (Diagon Ltd.).

\section{Statistical analysis of the results}

The reference range was set up on the basis of the measurement results of samples from dogs judged to be healthy. This group had normal distribution, as proved by the Shapiro-Wilk test. The $P$ value was 0.1071 and the $\mathrm{W}$ value was 0.9217 , which fall into the $95 \%$ acceptance range. Tumourpositive and tumour-negative groups were separated by the measured data, based on that reference range.

The D-dimer concentration results were displayed by box plots for tumour-bearing and healthy dogs (Tukey, 1977).

The differences between certain groups (tumour-bearing dogs, and certain tumour types compared to the control group) were analysed by non-parametric Wilcoxon-Mann-Whitney test. $P<0.05$ was considered to be a significant difference. Statistical calculations were carried out using Minitab 14.0 statistical software (Minitab Inc., State College, PA).

An attempt was made to determine the sensitivity and specificity of the Dia-D-Dimer test for tumour-bearing dogs. For this purpose, determination of tumour types was carried out according to their morphology, histology and immunohistochemistry (IHC) test results.

\section{RESULTS}

The distribution of D-dimer concentrations measured in the samples of tumour-bearing dogs (benign, malignant, and metastatic tumours) and in the control dog groups is shown in Table 1.

The median of D-dimer concentrations in the control and tumour-bearing groups and the concentration ranges are shown in Table 2. Based on the diagnosis, the different neoplasm types were divided into two groups and classified as malignant or benign tumours, where this classification could clearly be done. The D-dimer results of the benign tumour group did not differ significantly from those of the control group (median $=0.34 \mu \mathrm{g} / \mathrm{mL}$ FEU; $P=0.1310)$. However, the concentration values of the malignant group displayed significant differences from those of the control group (median $=0.68 \mu \mathrm{g} / \mathrm{mL} \mathrm{FEU;} P=0.0002$ ). Within the control group, $\mathrm{D}$-dimer concentration values were low and fell in the range of $0.10-0.58 \mu \mathrm{g} / \mathrm{mL} \mathrm{FEU}$, while in the tumour-bearing group the range was much wider, including the highest value of $28.20 \mu \mathrm{g} / \mathrm{mL}$ FEU.

The results of animals with metastatic cancer were examined separately as shown in Table 3. The median of Ddimer levels in samples of dogs with metastatic cancer was $1.01 \mu \mathrm{g} / \mathrm{mL}$ FEU, higher than that of the overall malignant tumour group. Similarly, a statistically significant difference was recorded between the metastatic and the control group $(P=0.0016)$.

The plasma samples were grouped also on the basis of the histological grades and stages of tumours where this information was available. The D-dimer concentration ranges and medians are indicated in Table 4. Regarding the grades, in case of grade I the median was $0.40 \mu \mathrm{g} / \mathrm{mL} \mathrm{FEU}$

Table 1. Distribution of D-dimer concentrations measured in the samples of tumour-bearing and control dogs

\begin{tabular}{lrcccc}
\hline & \multicolumn{5}{c}{ D-dimer $(\mu \mathrm{g} / \mathrm{mL}$ FEU) } \\
\cline { 2 - 6 } Group $(n)$ & $0.1-0.5$ & $0.5-1$ & $1-2$ & $2-3$ & $>3$ \\
\hline Control $(n=20)$ & 18 & 2 & - & - & - \\
Benign tumour $(n=8)$ & 6 & 2 & - & - & - \\
Malignant tumour $(n=$ & 17 & 6 & 6 & 2 & 5 \\
$\quad$ 36) \\
Metastasis $(n=6)$
\end{tabular}

$\mathrm{FEU}=$ fibrinogen equivalent unit.

Table 2. D-dimer concentration ranges measured in the control and the tumour-bearing dog groups, calculated medians and $P$ values for the evaluation of difference from the control group

\begin{tabular}{lcccc}
\hline \multirow{2}{*}{ Group $(n)$} & \multicolumn{3}{c}{ D-dimer $(\mu \mathrm{g} / \mathrm{mL}$ FEU $)$} \\
\cline { 2 - 5 } & Range & Median & $P$ value \\
\hline Control $(n=20)$ & $0.10-0.58$ & 0.25 & - \\
Neoplasia & Benign $(n=8)$ & $0.10-0.72$ & 0.34 & 0.1310 \\
& Malignant & $0.10-28.20$ & 0.68 & 0.0002 \\
& $(n=42)$ & & & \\
\hline
\end{tabular}


Table 3. D-dimer concentration ranges, calculated medians of the tumour-bearing animals and $P$ values for the evaluation of difference from the control group

\begin{tabular}{lccc}
\hline \multirow{2}{*}{ Group $(n)$} & \multicolumn{3}{c}{ D-dimer $(\mu \mathrm{g} / \mathrm{mL}$ FEU $)$} \\
\cline { 2 - 4 } & Range & Median & $P$ value \\
\hline Benign tumour $(n=8)$ & $0.10-0.72$ & 0.34 & 0.1310 \\
Malignant tumour $(n=36)$ & $0.10-15.50$ & 0.57 & 0.0007 \\
Metastasis $(n=6)$ & $0.25-28.20$ & 1.01 & 0.0016 \\
\hline
\end{tabular}

Table 4. D-dimer concentration ranges and medians in the case of tumours of different histological grades (A) and stages (B)

\begin{tabular}{lcc}
\hline \multirow{2}{*}{$A$} & \multicolumn{2}{c}{ D-dimer $(\mu \mathrm{g} / \mathrm{mL}$ FEU $)$} \\
\cline { 2 - 3 } Grade $(n)$ & Range & Median \\
\hline I $(n=22)$ & $0.10-15.50$ & 0.40 \\
II-III $(n=28)$ & $0.10-4.75$ & 0.94 \\
& & \\
\hline$B$ & D-dimer $(\mu \mathrm{g} / \mathrm{mL}$ FEU $)$ \\
\cline { 2 - 3 } Stages $(n)$ & Range & Median \\
\hline I-II-III $(n=40)$ & $0.10-4.74$ & 0.44 \\
IV-V $(n=10)$ & $0.19-28.20$ & 1.50 \\
\hline
\end{tabular}

while for grades II-III, a higher median $(0.94 \mu \mathrm{g} / \mathrm{mL}$ FEU $)$ was found. We also found that the medians increased in the case of higher stages $(1.50 \mu \mathrm{g} / \mathrm{mL} \mathrm{FEU})$.

We obtained outstandingly high D-dimer concentrations in the case of three samples. One of them was the sample of an 8 -year-old male Rottweiler with a value of $15.50 \mu \mathrm{g} / \mathrm{mL}$ FEU. This dog was diagnosed with biliary carcinoma. Another sample originated from a spayed female mongrel with mammary carcinoma with metastases in the thorax $(15.10 \mu \mathrm{g} / \mathrm{mL}$ FEU). The highest concentration value of $28.20 \mu \mathrm{g} / \mathrm{mL}$ FEU was measured in the sample of an 8-yearold, male Dogo Argentino with advanced-stage T-cell lymphoma.

The tumour-bearing groups were additionally examined on the basis of tumour type. The distribution of the measured D-dimer concentrations according to the different tumour types is shown in Table 5. Concentration ranges, calculated medians and $P$ values showing the difference of the groups from the control group are presented in Table 6.

The highest $\mathrm{D}$-dimer median was calculated in the group of dogs with malignant lymphoma $(1.72 \mu \mathrm{g} / \mathrm{mL}$ FEU). A significantly high concentration value of $0.83 \mu \mathrm{g} / \mathrm{mL}$ FEU was also acquired from the animal group suffering from carcinoma. In the group with lipoma and insulinoma, the medians were low, similar to those of the control group. It should be added that the sample number was low in these groups. According to the results of the Mann-Whitney statistical test, the mast cell tumour group $(P=0.1024)$ did not differ significantly from the control group. In contrast, the lymphoma $(P=0.0114)$, sarcoma $(P=0.0005)$ and carcinoma $(P=0.0022)$ groups displayed significant differences (Table 6).
Table 5. D-dimer concentration distributions in groups with certain tumour types and in the control group

\begin{tabular}{lrcccc}
\hline & \multicolumn{5}{c}{ D-dimer $(\mu \mathrm{g} / \mathrm{mL}$ FEU $)$} \\
\cline { 2 - 6 } Group $(n)$ & $0.1-0.5$ & $0.5-1$ & $1-2$ & $2-3$ & $>3$ \\
\hline Mast cell tumour $(n=6)$ & 4 & - & - & 2 & - \\
Lymphoma $(n=5)$ & 1 & 1 & 1 & - & 2 \\
Sarcoma $(n=10)$ & 4 & 4 & 1 & - & 1 \\
Carcinoma $(n=17)$ & 7 & 2 & 5 & - & 3 \\
Lipoma $(n=3)$ & 2 & 1 & - & - & - \\
Adenoma $(n=3)$ & 2 & 1 & - & - & - \\
Insulinoma $(n=3)$ & 2 & - & - & - & 1 \\
Other tumours $(n=3)$ & 3 & - & - & - & - \\
Control $(n=20)$ & 18 & 2 & - & - & - \\
\hline
\end{tabular}

Table 6. D-dimer concentration ranges and medians in groups with certain tumour types and in the control group

\begin{tabular}{|c|c|c|c|c|}
\hline \multirow[b]{2}{*}{ Tissue type } & \multirow{3}{*}{$\begin{array}{c}\text { Group }(n) \\
\text { Control } \\
(n=20)\end{array}$} & \multirow{2}{*}{\multicolumn{2}{|c|}{$\begin{array}{c}\text { Range Median } \\
\text { D-dimer } \\
(\mu \mathrm{g} / \mathrm{mL} \text { FEU })\end{array}$}} & \multirow{3}{*}{$\frac{P \text { value }}{-}$} \\
\hline & & & & \\
\hline & & $0.1-0.58$ & 0.25 & \\
\hline \multirow[t]{3}{*}{ Connective } & $\begin{array}{l}\text { Lipoma } \\
(n=3)\end{array}$ & $0.26-0.51$ & 0.31 & NA \\
\hline & $\begin{array}{l}\text { Mast cell } \\
\text { tumour } \\
(n=6)\end{array}$ & $0.10-2.38$ & 0.38 & 0.1024 \\
\hline & $\begin{array}{l}\text { Sarcoma } \\
(n=10)\end{array}$ & $0.12-3.77$ & 0.67 & 0.0005 \\
\hline \multirow[t]{2}{*}{ Epithelial } & $\begin{array}{l}\text { Adenoma } \\
(n=3)\end{array}$ & $0.10-0.72$ & 0.48 & NA \\
\hline & $\begin{array}{c}\text { Carcinoma } \\
(n=17)\end{array}$ & $0.10-15.5$ & 0.83 & 0.0022 \\
\hline $\begin{array}{c}\text { Lymphatic } \\
\text { system }\end{array}$ & $\begin{array}{l}\text { Lymphoma } \\
\quad(n=5)\end{array}$ & $0.14-28.2$ & 1.72 & 0.0114 \\
\hline Exocrine & $\begin{array}{c}\text { Insulinoma } \\
\quad(n=3)\end{array}$ & $0.10-3.85$ & 0.25 & NA \\
\hline- & $\begin{array}{l}\text { Other } \\
\text { tumours } \\
(n=3)\end{array}$ & $0.10-0.37$ & 0.26 & NA \\
\hline
\end{tabular}

NA: Not applicable due to lack of type or low statistical power.

The correlations between certain groups and the control group are presented as a box plots in Figs. 1 and 2.

Based on the values measured in healthy dogs, we propose to set up a reference range of $0.06-0.69 \mu \mathrm{g} / \mathrm{mL}$ FEU that can be used for the analysis of plasma samples from dogs with neoplasms.

Positive and negative groups were created from the measured data based on this reference range. The sensitivity, specificity, positive and negative predictive values (PPV and NPV) of the Dia-D-Dimer test were also calculated with altered cut-off values, based on the diagnosis of the dogs (healthy and not healthy categories). According to our results, with cut-off values extending to $0.30-0.69 \mu \mathrm{g} / \mathrm{mL} \mathrm{FEU}$, sensitivity was between 33 and $51 \%$, while specificity was between 85 and 100\% (Table 7). By the application of the 


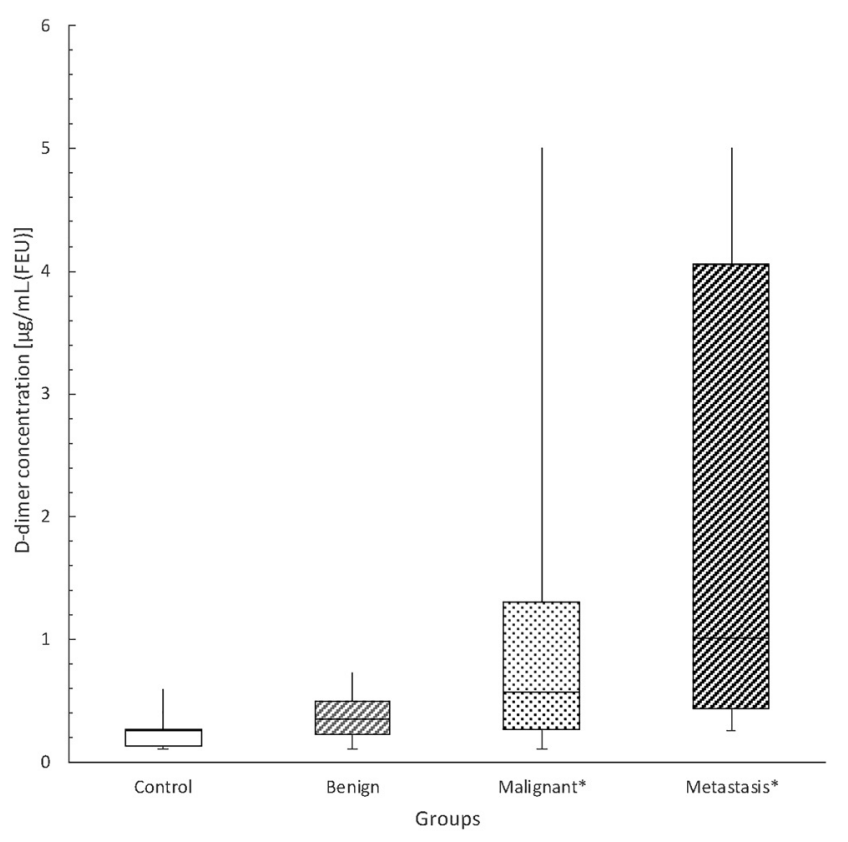

Fig. 1. Box plot display of the D-dimer concentrations of the control group and of dogs with benign, malignant, and metastatic tumours. Asterisks indicate significant difference from the control group

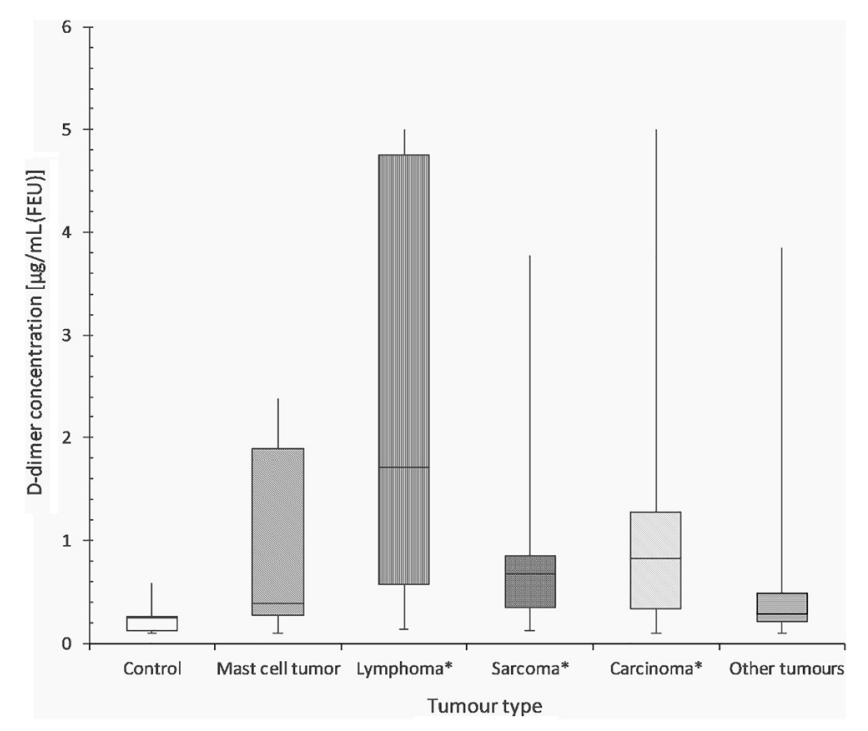

Fig. 2. Box plot display of the D-dimer concentrations of the control group and of certain tumour type groups. Asterisks indicate significant difference from the control group

upper limit of the reference range $(0.69 \mu \mathrm{g} / \mathrm{mL}$ FEU), with $33 \%$ sensitivity, we reached $100 \%$ specificity. The PPV increased to $100 \%$ and the NPV was $29 \%$ for samples of tumour-bearing dogs.

Therefore, when using the Dia-D-Dimer test, samples with a concentration lower than the cut-off value of 0.69 $\mu \mathrm{g} / \mathrm{mL}$ FEU should be regarded as negative in respect of malignancy, while samples with results above that value should be considered likely to come from a malignant tumour case.
Table 7. Sensitivity, specificity, positive predictive value (PPV) and negative predictive value (NPV) values of the Dia-D-Dimer test for tumours, expressed in percentages, with the application of different cut-off values

\begin{tabular}{lcccc}
\hline $\begin{array}{l}\text { D-dimer cut-off } \\
(\mu \mathrm{g} / \mathrm{mL} \mathrm{FEU})\end{array}$ & $\begin{array}{c}\text { Sensitivity } \\
\%\end{array}$ & $\begin{array}{c}\text { Specificity } \\
\%\end{array}$ & $\begin{array}{c}\text { PPV } \\
\%\end{array}$ & $\begin{array}{c}\text { NPV } \\
\%\end{array}$ \\
\hline$>0.3$ & 51 & 85 & 92.5 & 32.1 \\
$>0.4$ & 41 & 85 & 90.9 & 28.3 \\
$>0.5$ & 37 & 90 & 93.1 & 28.1 \\
$>0.6$ & 33 & 100 & 100 & 29 \\
$>0.69$ & 33 & 100 & 100 & 29 \\
\hline
\end{tabular}

\section{DISCUSSION}

The results of our examinations supported the findings of the publications mentioned above, i.e. that the anti-human D-dimer specific monoclonal antibody reacts with the Ddimer in canine samples and that the Dia-D-Dimer test can be applied for the analysis of canine samples.

Although increased D-dimer levels may suggest thromboembolism, patients with tumour, inflammatory diseases and surgery may also provide positive results (Stokol, 2003; Morii et al., 2008). However, in veterinary medicine, the Ddimer assay is mostly used for the diagnosis of pulmonary embolism and DIC.

Our results showed that the concentrations measured in the tumour group were significantly higher than those found in the control group. These results are in line with other reports from the literature, mainly based on the analysis of human samples (Adamson et al., 1993; Gabazza et al., 1993; Gadducci et al., 1993; Nakashima et al., 1995; Blackwell et al., 2000; Dirix et al., 2002; Altiay et al., 2007; Khan et al., 2007; Kilic et al., 2008; Morii et al., 2008; Khoury et al., 2010; Nagy et al., 2012).

Nelson and Andreasen (2003) examined a group of dogs with neoplasia, where 7 out of 16 dogs were found to have increased D-dimer levels. The neoplastic group represented a borderline difference from the control group $(P=0.06)$. After having analysed multiple disease groups simultaneously, Dewhurst et al. (2008) reported that dogs with neoplasia had the highest D-dimer concentration $(1.7 \mathrm{mg} / \mathrm{L}=3.4 \mu \mathrm{g} / \mathrm{mL}$ FEU), a value that is similar to our results, supporting a correlation between increased D-dimer levels and neoplasia.

In the groups of dogs suffering from malignant lymphoma, sarcoma, and carcinoma, the D-dimer levels were found to be significantly higher than in the control group.

We did not find a significant difference between the values of dogs with malignant mast cell tumour and those of the control group. Moreover, in the group of dogs with benign lipoma and insulinoma, the median of the $\mathrm{D}$-dimer concentration was almost the same as in the control groups.

In a Pakistani study, D-dimer and platelet concentrations were examined in healthy dogs and in dogs with a number of different diseases. Six disease groups were examined, including a group of dogs suffering from neoplasia $(n=28)$. It was shown that the D-dimer concentration was significantly increased in this cohort (Kang et al., 2016). 
Andreasen et al. (2012) examined coagulation and fibrinolysis parameters in 71 dogs with malignant tumours and compared the changes in haemostatic parameters with the type of the tumour and progression of the disease. No differences were found in the D-dimer values between the animal groups suffering from different tumours (carcinoma, sarcoma, mast cell tumour, and lymphoma). The study was also extended to monitoring the progression of tumours, and dogs with distant metastatic disease had significantly higher fibrinogen and $\mathrm{D}$-dimer values than dogs with locally invasive and locally non-invasive tumours (Andreasen et al., 2012).

We also found that the presence of metastases and the aggressiveness of the tumours are reflected in the D-dimer results. As compared to the control group, the analysis of the plasma samples of dogs in the malignant and metastatic tumour groups displayed significantly higher D-dimer concentrations. Three outstandingly high D-dimer levels were measured, as mentioned above. One of them was a dog with mammary carcinoma with metastasis in the thorax (Stage 5), while the other dog had T-cell lymphoma (Stage 4). The third dog was diagnosed with biliary carcinoma without information about metastases.

Morii et al. (2008) came to a similar conclusion when examining the samples of 77 human patients with tumour. According to their results, the $\mathrm{D}$-dimer values were significantly higher for malignant tumours than for benign tumours.

Recent studies have revealed that plasma D-dimer levels are correlated with the stage and grade of the tumour (Kwon et al., 2008; Batschauer et al., 2010; Morii et al., 2011). Our results support the findings reported in the above-mentioned publications, thus confirming the correlation between higher tumour grade or stage and the increased D-dimer value.

It should be noted that in the veterinary literature on canine cancers, we did not find any information on the sensitivity and specificity of D-dimer level measurements. The data presented in Table 7 show that the alteration of the cut-off value significantly changes the sensitivity and specificity of the assay. In our examinations, the determined cutoff value $(<0.69 \mu \mathrm{g} / \mathrm{mL} \mathrm{FEU})$ was higher than the cut-off value recommended by the manufacturer for the exclusion of deep vein thrombosis or pulmonary embolism in humans $(<0.5 \mu \mathrm{g} / \mathrm{mL}$ FEU $)$. With this cut-off value the test reached a high specificity and PPV, thus approximately $100 \%$ of dogs with a negative test result were clinically healthy. However, due to the low sensitivity of the test, only $33 \%$ of dogs diagnosed with cancer showed a positive test result.

Our results suggest that the examined Dia-D-Dimer diagnostic test is suitable for determining $\mathrm{D}$-dimer levels in canine samples. However, further research is required to determine the magnitude of the diagnostic value of increased $\mathrm{D}$-dimer levels in the prognosis of tumours in dogs and other animal species.

\section{ACKNOWLEDGEMENT}

The authors thank Dr Zoltán Vajda for his help with the statistical calculations.

\section{REFERENCES}

Adamson, A. S., Francis, J. L., Witherow, R. O. and Snell, M.E. (1993): Coagulopathy in the prostate cancer patient: prevalence and clinical relevance. Ann. R. Coll. Surg. Engl. 75, 100-104.

Altiay, G., Ciftci, A., Demir, M., Kocak, Z., Sut, N., Tabakoglu, E., Hatipoglu, O. N. and Caglar, T. (2007): High plasma D-dimer level is associated with decreased survival in patients with lung cancer. Clin. Oncol. 19, 494-498.

Andreasen, E. B., Tranholm, M., Wiinberg, B., Markussen, B. and Kristensen, A. T. (2012): Haemostatic alterations in a group of canine cancer patients are associated with cancer type and disease progression. Acta Vet. Scand. 54, 3.

Batschauer, A. P., Figueiredo, C. P., Bueno, E. C., Ribeiro, M. A., Dusse, L. M., Fernandes, A. P., Gomes, K. B. and Carvalho, M. G. (2010): D-dimer as a possible prognostic marker of operable hormone receptor-negative breast cancer. Ann. Oncol. 21, $1267-1272$.

Blackwell, K., Haroon, Z., Broadwater, G., Berry, D., Harris, L., Iglehart, J. D., Dewhirst, M. and Greenberg, C. (2000): Plasma $\mathrm{D}$-dimer levels in operable breast cancer patients correlate with clinical stage and axillary lymph node status. J. Clin. Oncol. 18, 600-608.

Caldin, M., Furlanello, T. and Lubas, G. (2000): Validation of an immunoturbidimetric D-Dimer assay in canine citrated plasma. Vet. Clin. Pathol. 29, 51-54.

de la Fuente, C., Pumarola, M., Blasco, E., Fernández, F., Viu, J. and Añor, S. (2014): Immunohistochemical evaluation of tissue factor, fibrin/fibrinogen and D-dimers in canine gliomas. Vet. J. 200, 387-392.

Dewhurst, E., Cue, S., Crawford, E. and Papasouliotis, K. (2008): A retrospective study of canine $\mathrm{D}$-dimer concentrations measured using an immunometric 'point-of-care' test. J. Small Anim. Pract. 49, 344-348.

Dirix, L. Y., Salgado, R., Weytjens, R., Colpaert, C., Benoy, I., Huget, P., van Dam, P., Prové, A., Lemmens, J. and Vermeulen, P. (2002): Plasma fibrin D-dimer levels correlate with tumour volume, progression rate and survival in patients with metastatic breast cancer. Br. J. Cancer. 86, 389-395.

Epstein, S. E., Hopper, K., Mellema, M. S. and Johnson, L. R. (2013): Diagnostic utility of D-dimer concentrations in dogs with pulmonary embolism. J. Vet. Intern. Med. 27, 16461649.

Falanga, A. and Rickles, F. R. (1999): Pathophysiology of the thrombophilic state in cancer patient. Semin. Thromb. Hemost. 25, 173-182.

Font, C., de la Fuente, C., Pumarola, M., Blasco, E., Fernández, F., Viu, J. and Añor, S. (2015): Canine intracranial meningiomas: Immunohistochemical evaluation of tissue factor, fibrin/ fibrinogen and D-dimers. Vet. J. 206, 426-428.

Gabazza, E. C., Taguchi, O., Yamakami, T., Machishi, M., Ibata, H. and Suzuki, S. (1993): Evaluating prethrombotic state in lung cancer using molecular markers. Chest 103, 196-200.

Gadducci, A., Baicchi, U., Marrai, R., Facchini, V., del Bravo, B., Fosella, P. V. and Fioretti, P. (1993): Pretreatment plasma levels of fibrinopeptide-A (FPA), D-dimer (DD), and von Willebrand factor (vWF) in patients with operable cervical cancer: 
influence of surgical-pathological stage, tumor size, histologic type, and lymph node status. Gynecol. Oncol. 49, 354-358.

Giannoulopoulos, G., Athanasiou, L. and Polizopoulou, Z. (2017): D-dimer as a diagnostic tool for canine thromboembolic disorders. J. Hell. Vet. Med. Soc. 61, 49-56.

Griffin, A., Callan, M. B., Shofer, F. S. and Giger, U. (2003): Evaluation of a canine D-dimer point-of-care test kit for use in samples obtained from dogs with disseminated intravascular coagulation, thromboembolic disease, and hemorrhage. Am. J. Vet. Res. 64, 1562-1569.

Kang, M. H., Heo, R. Y. and Park, H. M. (2016): Evaluation of Ddimer concentrations in clinically ill dogs with high risk of thromboembolic disease. Pak. Vet. J. 36, 219-223.

Khan, M. Z., Khan, M. S., Raziq, F. and Khattak, A. M. (2007): Fibrinogen degradation products and D-Dimer in patients with breast carcinoma. Gomal. J. Med. Sci. 5, 9-12.

Khoury, J. D., Adcock, D. M., Chan, F., Symanowski, J. T., Tiefenbacher, S., Goodman, O., Paz, L., Ma, Y., Ward, D. C., Vogelzang, N. J. and Fink, L. M. (2010): Increases in quantitative D-dimer levels correlate with progressive disease better than circulating tumor cell counts in patients with refractory prostate cancer. Am. J. Clin. Pathol. 134, 964-969.

Kilic, M., Yoldas, O., Keskek, M., Ertan, T., Tez, M., Gocmen, E. and Koc, M. (2008): Prognostic value of plasma D-dimer levels in patients with colorectal cancer. Colorectal. Dis. 10, 238-241.

Kwon, H. C., Oh, S. Y., Lee, S., Kim, S. H., Han, J. Y., Koh, R. Y., Kim, M. C. and Kim, H. J. (2008): Plasma levels of prothrombin fragment $\mathrm{F} 1+2$, D-dimer and prothrombin time correlate with clinical stage and lymph node metastasis in operable gastric cancer patients. Jpn. J. Clin. Oncol. 38, 2-7.

Machida, T., Kokubu, H., Matsuda, K., Miyoshi, K. and Uchida, E. J. (2010): Clinical use of D-dimer measurement for the diagnosis of disseminated intravascular coagulation in dogs. Vet. Med. Sci. 72, 1301-1306.

Morii, T., Mochizuki, K., Kotera, M., Imakiire, N., Moriwaki, T. and Satomi, K. (2008): Perioperative D-Dimer levels in patients with musculoskeletal tumors. Open. Orthop. J. 2, 130-132.

Morii, T., Mochizuki, K., Tajima, T., Ichimura, S. and Satomi, K. (2011): D-dimer levels as a prognostic factor for determining oncological outcomes in musculoskeletal sarcoma. BMC Musculoskelet. Disord. 12, 250.

Nagy, Z., Horváth, O., Kádas, J., Valtinyi, D., László, L., Kopper, B. and Blaskó, G. (2012): D-dimer as a potential prognostic marker. Pathol. Oncol. Res. 18, 669-674.
Nakashima, J., Tachibana, M., Ueno, M., Baba, S. and Tazaki, H. (1995): Tumor necrosis factor and coagulopathy in patients with prostate cancer. Cancer Res. 55, 4881-4885.

Nelson, O. L. (2005): Use of the D-dimer assay for diagnosing thromboembolic disease in the dog. J. Am. Anim. Hosp. Assoc. 41, 145-149.

Nelson, O. L. and Andreasen, C. (2003): The utility of plasma Ddimer to identify thromboembolic disease in dogs. J. Vet. Intern. Med. 17, 830-834.

Nelson, C. M., Wright, G. S., Silbaugh, T. R. and Cota, L. J. (2009): Improving $\mathrm{D}$-dimer positive predictive value for outpatients with suspected deep vein thrombosis. Perm. J. 13, 4-7.

Olson, J. D., Adcock, D. M., Bush, T. A., de Moerloose, P., Gardiner, C., Ginyard, V. R., Grimaux, M., McMahan, C. A., Prihoda, T. J., Rico-Lazarouski, A., Sales, M., Stang, L., Trumbull, K., VanCott, E. M. and Wissel, T. (2011): Clinical and laboratory standards institute (CLSI). Quantitative D-dimer for the exclusion of venous thromboembolic disease; Approved Guideline. CLSI Document H59-A. ISBN 1-56238-747-2, pp. 8-12.

Owen, L. M. (1980): TNM Classification of Tumors in Domestic Animals. World Health Organization, Geneva 461, 53.

Stokol, T. (2003): Plasma D-dimer for the diagnosis of thromboembolic disorders in dogs. Vet. Clin. Small. Anim. 33, 14191435.

Stokol, T., Brooks, M. B., Erb, H. N. and Mauldin, G. E. (2000): Ddimer concentrations in healthy dogs and dogs with disseminated intravascular coagulation. Am. J. Vet. Res. 61, 393-398.

Tick, L. W., Nijkeuter, M., Kramer, M. H., Hovens, M. M., Buller, H. R., Leebeek, F. W. and Huisman, M. V. (2008): High Ddimer levels increase the likelihood of pulmonary embolism. J. Intern. Med. 264, 195-200.

Török-Nagy, B., Antal, J. and Dénes, B. (2019a): Generation and characterization of D-dimer specific monoclonal antibodies for use in latex agglutination test. PLoS One 14, e0212104.

Török-Nagy, B., Vajda, Z. and Vásárhelyi, B. (2019b): Harmonization of cut-off values of commercially available D-dimer tests [in Hungarian, with English abstract]. Orv. Hetil. 160, 585-592.

Tukey, J. W. (1977): Exploratory Data Analysis. Addison-Wesley Publishing Company, Reading, MA, Menlo Park, CA, London, Amsterdam, Don Mills, Ontario, Sydney, Tokyo XVI. p. 688.

Weiser, G. and Allison, R. W. (2012): Perspectives in laboratory data interpretation and disease diagnosis. In: Thrall, M. A., Weiser, G., Allison, R. and Campbell, T. (eds) Veterinary Hematology and Clinical Chemistry. 2nd edition. Wiley-Blackwell. p. 784. 


\section{APPENDIX}

Table A1. Description of the population of the tumour-bearing dogs examined

\begin{tabular}{|c|c|c|c|c|c|c|c|c|c|}
\hline $\begin{array}{l}\text { Tumour } \\
\text { type }\end{array}$ & $\begin{array}{c}\text { Age } \\
\text { (years) }\end{array}$ & Breed & Gender & Stage & Grade & Localisation & & Metastasis & Histopathology \\
\hline $\begin{array}{l}\text { Mast cell } \\
\text { tumour }\end{array}$ & 1.5 & Pinscher & Male & 1 & 1 & Skin & Leg & No & \\
\hline $\begin{array}{l}\text { Mast cell } \\
\text { tumour }\end{array}$ & 14 & Fox Terrier & Male & 1 & 2 & Skin & Leg & No & \\
\hline $\begin{array}{l}\text { Mast cell } \\
\text { tumour }\end{array}$ & 13 & Mongrel & Male & 1 & 2 & Skin & $\begin{array}{l}\text { Trunk } \\
\text { (flank) }\end{array}$ & No & \\
\hline $\begin{array}{l}\text { Mast cell } \\
\text { tumour }\end{array}$ & 5.5 & Mongrel & Female & 3 & 2 & Skin & Head & No & \\
\hline $\begin{array}{l}\text { Mast cell } \\
\text { tumour }\end{array}$ & 3.5 & Boxer & Female & 1 & 2 & Skin & Neck & No & \\
\hline $\begin{array}{l}\text { Mast cell } \\
\text { tumour }\end{array}$ & 6 & $\begin{array}{c}\text { American } \\
\text { Staffordshire } \\
\text { Terrier }\end{array}$ & Male & 3 & 2 & Skin & $\begin{array}{l}\text { Trunk } \\
\text { (chest) }\end{array}$ & No & \\
\hline Lymphoma & 11 & Beagle & Female & 1 & 1 & Skin & $\begin{array}{l}\text { Neck and } \\
\text { back }\end{array}$ & No & $\begin{array}{l}\text { Epithelial T-cell } \\
\text { lymphoma }\end{array}$ \\
\hline Lymphoma & 7 & Mongrel & Female & 2 & 1 & Lymph node & Multicentric & No & $\begin{array}{l}\text { Indolent T-cell } \\
\text { lymphoma }\end{array}$ \\
\hline Lymphoma & 10 & Mongrel & Male & 5 & 2 & Mediastinum & & No & $\begin{array}{l}\text { Mediastinal T-cell } \\
\text { lymphoma }\end{array}$ \\
\hline Lymphoma & 13 & Mongrel & Male & 5 & 3 & Spleen & & No & B-cell lymphoma \\
\hline Lymphoma & 8 & Dogo Argentino & Male & 4 & 2 & Lymph node & Multicentric & Yes & $\begin{array}{l}\text { Peripheral T-cell } \\
\text { lymphoma }\end{array}$ \\
\hline Sarcoma & 7 & Irish Setter & Male & 1 & 1 & Spleen & & No & Fibrosarcoma \\
\hline Sarcoma & 6.5 & $\begin{array}{l}\text { German } \\
\text { Shepherd }\end{array}$ & Male & 2 & 1 & Nasal cavity & & No & Chondrosarcoma \\
\hline Sarcoma & 9 & French Bulldog & Female & 2 & 2 & Front leg & $\begin{array}{l}\text { Metacarpal } \\
\text { area }\end{array}$ & No & Fibrosarcoma \\
\hline Sarcoma & 9 & Boxer & Male & 3 & 3 & Front leg & $\begin{array}{l}\text { Distal } \\
\text { radius }\end{array}$ & No & Osteosarcoma \\
\hline Sarcoma & 10 & Akita & Female & 3 & 2 & Hind limb & $\begin{array}{l}\text { Proximal } \\
\text { tibia }\end{array}$ & No & Osteosarcoma \\
\hline Sarcoma & 8 & Mongrel & Male & 1 & 1 & Thigh & & No & $\begin{array}{l}\text { Peripheral nerve } \\
\text { sheath tumour }\end{array}$ \\
\hline Sarcoma & 11 & Mongrel & Male & 1 & 1 & Hind limb & $\begin{array}{l}\text { Distal } \\
\text { femur }\end{array}$ & No & Fibrosarcoma \\
\hline Sarcoma & 12 & English Setter & Male & 1 & 3 & Oral cavity & & No & Fibrosarcoma \\
\hline Sarcoma & 10 & Pit Bull terrier & Female & 1 & 1 & Skin & Chest & No & Fibrosarcoma \\
\hline Sarcoma & 11 & $\begin{array}{c}\text { Bernese } \\
\text { Mountain Dog }\end{array}$ & Female & 1 & 1 & Skin & Neck & No & Fibrosarcoma \\
\hline Carcinoma & 12 & Fox Terrier & Female & 4 & 3 & $\begin{array}{l}\text { Thyroid } \\
\text { gland }\end{array}$ & & Yes & Adenocarcinoma \\
\hline Carcinoma & 8 & Puli & Female & 4 & 2 & $\begin{array}{l}\text { Mammary } \\
\text { gland }\end{array}$ & & Yes & $\begin{array}{c}\text { Tubulopapillary } \\
\text { simplex carcinoma }\end{array}$ \\
\hline Carcinoma & 8 & $\begin{array}{l}\text { Doberman } \\
\text { Pinscher }\end{array}$ & Male & 3 & 3 & Oral cavity & & Yes & $\begin{array}{l}\text { Squamous cell } \\
\text { carcinoma }\end{array}$ \\
\hline Carcinoma & 6 & Mongrel & Female & 5 & 3 & Lung & & Yes & $\begin{array}{l}\text { Tubulopapillary } \\
\text { carcinoma }\end{array}$ \\
\hline Carcinoma & 10 & $\begin{array}{l}\text { Miniature } \\
\text { Poodle }\end{array}$ & Female & 2 & 2 & $\begin{array}{l}\text { Mammary } \\
\text { gland }\end{array}$ & & No & Solid carcinoma \\
\hline Carcinoma & 8 & $\begin{array}{l}\text { Labrador } \\
\text { Retriever }\end{array}$ & Male & 2 & 2 & $\begin{array}{l}\text { Urine } \\
\text { bladder }\end{array}$ & & No & $\begin{array}{c}\text { Transitional cell } \\
\text { carcinoma }\end{array}$ \\
\hline Carcinoma & 11.5 & Mongrel & Male & 3 & 2 & Prostate & & No & Prostate carcinoma \\
\hline Carcinoma & 8 & Puli & Male & 4 & 2 & Oral cavity & & No & $\begin{array}{l}\text { Squamous cell } \\
\text { carcinoma } \\
\text { (continued }\end{array}$ \\
\hline
\end{tabular}


Table A1. Continued

\begin{tabular}{|c|c|c|c|c|c|c|c|c|c|}
\hline $\begin{array}{l}\text { Tumour } \\
\text { type }\end{array}$ & $\begin{array}{l}\text { Age } \\
\text { (years) }\end{array}$ & Breed & Gender & Stage & Grade & Localisation & & Metastasis & Histopathology \\
\hline Carcinoma & 10 & Mongrel & Male & 2 & 2 & Lung & & No & Small cell carcinoma \\
\hline Carcinoma & 7.5 & Mongrel & Female & 2 & 2 & Skin & Chin & No & $\begin{array}{l}\text { Squamous cell } \\
\text { carcinoma }\end{array}$ \\
\hline Carcinoma & 13 & Mongrel & Male & 3 & 2 & Liver & & No & Biliary carcinoma \\
\hline Carcinoma & 10 & French Bulldog & Male & 4 & 2 & Prostate & & No & Prostate carcinoma \\
\hline Carcinoma & 8 & Rottweiler & Male & 4 & 1 & Liver & & No & Biliary carcinoma \\
\hline Carcinoma & 9 & $\begin{array}{l}\text { Yorkshire } \\
\text { Terrier }\end{array}$ & Female & 2 & 1 & $\begin{array}{l}\text { Mammary } \\
\text { gland }\end{array}$ & & No & $\begin{array}{l}\text { Tubulopapillary } \\
\text { simplex carcinoma }\end{array}$ \\
\hline Carcinoma & 6 & $\begin{array}{l}\text { Golden } \\
\text { Retriever }\end{array}$ & Female & 3 & 3 & Nasal cavity & & No & $\begin{array}{l}\text { Anaplastic } \\
\text { carcinoma }\end{array}$ \\
\hline Carcinoma & 11 & $\begin{array}{l}\text { Bichon } \\
\text { Havanese }\end{array}$ & Male & 4 & 3 & Prostate & & No & Prostate carcinoma \\
\hline Carcinoma & 7 & French Bulldog & Female & 1 & 1 & $\begin{array}{l}\text { Mammary } \\
\text { gland }\end{array}$ & & No & $\begin{array}{l}\text { Tubulopapillary, } \\
\text { complex carcinoma }\end{array}$ \\
\hline Leukaemia & 4.5 & $\begin{array}{c}\text { Staffordshire } \\
\text { Terrier }\end{array}$ & Male & 2 & 2 & Blood & & No & $\begin{array}{c}\text { Myelogenous } \\
\text { leukaemia, acute } \\
\text { AML5a }\end{array}$ \\
\hline Insulinoma & 8 & Mongrel & Male & 2 & 1 & Pancreas & & No & Insulinoma \\
\hline Insulinoma & 9 & Mongrel & Male & 2 & 1 & Pancreas & & No & Insulinoma \\
\hline Insulinoma & 12 & Mongrel & Female & 3 & 2 & Pancreas & & Yes & Insulinoma \\
\hline Lipoma & 9 & $\begin{array}{l}\text { Labrador } \\
\text { Retriever }\end{array}$ & Female & 1 & 1 & Skin & Axillar area & No & \\
\hline Lipoma & 12 & $\begin{array}{l}\text { Bichon } \\
\text { Havanese }\end{array}$ & Female & 1 & 1 & Skin & Sternal area & No & \\
\hline Lipoma & 10.5 & Mongrel & Female & 1 & 1 & Skin & Axillar area & No & \\
\hline Adenoma & 10 & Mongrel & Female & 1 & 1 & $\begin{array}{l}\text { Mammary } \\
\text { gland }\end{array}$ & & No & Papillary adenoma \\
\hline Adenoma & 12 & Mongrel & Male & 1 & 1 & Perianal area & & No & $\begin{array}{l}\text { Perianal gland } \\
\text { adenoma }\end{array}$ \\
\hline Adenoma & 9.5 & $\begin{array}{l}\text { Yorkshire } \\
\text { Terrier }\end{array}$ & Female & 1 & 1 & $\begin{array}{l}\text { Mammary } \\
\text { gland }\end{array}$ & & No & $\begin{array}{c}\text { Intraductal papillary } \\
\text { adenoma }\end{array}$ \\
\hline $\begin{array}{l}\text { Benign } \\
\text { mixed } \\
\text { tumour }\end{array}$ & 9 & $\begin{array}{l}\text { Yorkshire } \\
\text { Terrier }\end{array}$ & Female & 1 & 1 & $\begin{array}{l}\text { Mammary } \\
\text { gland }\end{array}$ & & No & $\begin{array}{l}\text { Benign mixed } \\
\text { tumour }\end{array}$ \\
\hline Papilloma & 10.5 & $\begin{array}{l}\text { West Highland } \\
\text { White Terrier }\end{array}$ & Male & 1 & 1 & $\begin{array}{l}\text { Mammary } \\
\text { gland }\end{array}$ & & No & Papilloma \\
\hline
\end{tabular}

Open Access. This is an open-access article distributed under the terms of the Creative Commons Attribution 4.0 International License (https://creativecommons.org/ licenses/by/4.0/), which permits unrestricted use, distribution, and reproduction in any medium, provided the original author and source are credited, a link to the CC License is provided, and changes - if any - are indicated. (SID_1) 